\title{
Review \\ Self-Compacting Alkali-Activated Materials: Progress and Perspectives
}

\author{
Zengqing Sun, Qingyu Tang, Xiaohui Fan *, Min Gan, Xuling Chen, Zhiyun Ji and Xiaoxian Huang \\ School of Minerals Processing and Bioengineering, Central South University, Changsha 410083, China \\ * Correspondence: csufanxiaohui@126.com; Tel./Fax: +86-731-8883-0542
}

check for updates

Citation: Sun, Z.; Tang, Q.; Fan, X.; Gan, M.; Chen, X.; Ji, Z.; Huang, X. Self-Compacting Alkali-Activated Materials: Progress and Perspectives. Molecules 2022, 27, 81. https:// doi.org/10.3390/molecules27010081

Academic Editors: Ruby Mejía de Gutiérrez and Francisca Puertas

Received: 28 October 2021

Accepted: 14 December 2021

Published: 23 December 2021

Publisher's Note: MDPI stays neutral with regard to jurisdictional claims in published maps and institutional affiliations.

Copyright: (C) 2021 by the authors. Licensee MDPI, Basel, Switzerland. This article is an open access article distributed under the terms and conditions of the Creative Commons Attribution (CC BY) license (https:// creativecommons.org/licenses/by/ $4.0 /)$.

\begin{abstract}
Alkali-activated materials (AAMs) are considered to be alternative cementitious materials for civil infrastructures. Nowadays, efforts have been made in developing AAMs with selfcompacting ability. The obtained self-compacting AAMs (SCAAMs) accomplish superior passing and filling properties as well as excellent mechanical and environmental advantages. This work critically revisits recent progresses in SCAAMs including mixture proportions, fresh properties, mechanical strength, microstructure, acid and sulfate resistance, high temperature behaviors, impact resistance and interface shear strength. To facilitate direct comparison and interpretation of data from different publications, mixture proportions were normalized in terms of the content of key reactive components from precursors and activators, and correlation with mechanical behaviors was made. Moreover, special attention was paid to current research challenges and perspectives to promote further investigation and field application of SCAAMs as advanced construction material.
\end{abstract}

Keywords: self-compacting; alkali-activated materials; workability; mechanical strength; durability

\section{Introduction}

Self-compacting concrete (SCC) is a kind of concrete that can be placed without any mechanical consolidation while keeping stable composition [1,2]. The history of SCC can be dated back to 1986, when Okamura first proposed the concept [3], and in 1988, when Ozawa from the University of Tokyo developed the prototype [4]. Extensive investigations have since been conducted on the production and placement of SCC, as well as the characterization of fresh and hardened properties $[1,2,5,6]$. In general, SCC possess advantages such as eliminated vibration need, improved filling capacity, decreased permeability, enhanced durability, reduced construction time and labor cost, etc. [7-11]. Thus, SCC can be used particularly in pre-cast, high rise buildings requiring congested reinforcement.

The construction industry is now seeking alternative cementitious materials, partially because the production of cement clinker is associated with huge amounts of greenhouse gas emissions. It is estimated that cement production alone accounts for approximately $8 \%$ of global overall $\mathrm{CO}_{2}$ emission [12-16]. Alkali-activated materials (AAMs) are among the more robust candidates, with excellent engineering properties and reduced $\mathrm{CO}_{2}$ emission. Solid precursors used for AAM production are normally industrial and agricultural byproducts/wastes, such as ground granulated blast furnace slag (GGBS), fly ash (FA), coal gangue, red mud, rice husk ash (RHA), etc. Depending on the reaction mechanism stemming from initial mixture proportion, AAMs are generally divided into high-calcium systems (with the representative of alkali activated GGBS (AAS)) and low-calcium systems (also known as geopolymer) [17]. The differences in reaction processes and products have been well investigated and documented $[17,18]$. Studies have reported that AAMs possess properties including high mechanical strength, thermal and chemical resistance, strong adhesion to different surfaces, etc. Hence, AAMs have been successfully utilized in the production of masonry blocks, retail buildings, storehouses, drainage systems, and even airport pavement since the 1970s [18-20]. 
Nowadays, developments have also been made in self-compacting AAMs (SCAAMs), which combines the advantages of superior passing and filling properties of SCC with the excellent mechanical and environmental properties of AAMs. Memon et al. synthesized SCAAMs using FA as solid source and characterized the influence of activator concentration, liquid-solid ratio and curing temperature [21-25]. Manjunath and Narasimhan investigated the flowability, passing ability, compressive strength, and water absorption of slag-based SCAAM [26]. Based on the findings, mixtures with high performances, i.e., compressive strength up to $90 \mathrm{MPa}$ and water absorption of 2.1-2.7\%, were produced [27]. While in [9,28-30], RHA, nano silica (NS), ceramic powder (CP) and Wollastonite were independently utilized as reactive additive. All these facilitate the investigation of SCAAMs synthesis and properties, but also make it difficult to compare the obtained results and figure out the dominating parameters.

In this review, the synthesis of SCAAMs based on different precursors and mixture proportions was outlined. For comparison and discussion, mixtures were recalculated and normalized in terms of the content of key reactive components from precursors and activators. Workability, mechanical properties, microstructure, acid and sulfate resistance, high temperature behaviors, impact resistance and interface shear strength were addressed. Special attention is paid to current research challenges and perspectives to boost further investigation and promote field application of SCAAMs.

\section{Materials and Formulations}

GGBS and FA are among the most frequently used solid precursors for AAM production including SCAAMs. The physical and chemical characteristics of these materials have been well characterized and described in literature [17,31,32]. Recently, studies have been conducted using other materials as solid sources for SCAAMs preparation. These solid materials provide desirable properties, minimize the total environmental footprint, and widen the sources and types of precursors, which are briefly described in this section.

\subsection{New Precursors}

\subsubsection{Rice Husk Ash}

RHA is a typical and plentifully accessible agricultural waste generated from rice milling plants during the burning of husk under controlled temperature. According to a report from the Food and Agricultural Organization (FAO), 741.3 million tons of RHA was produced all over the world [28]. RHA is predominantly composed of $\mathrm{SiO}_{2}$, which can be $80-95 \%$ of its total. $\mathrm{CaO}, \mathrm{MgO}, \mathrm{K}_{2} \mathrm{O}, \mathrm{Al}_{2} \mathrm{O}_{3}, \mathrm{Fe}_{2} \mathrm{O}_{3}$ and $\mathrm{Na}_{2} \mathrm{O}$ are frequently detected in RHA but in minor quantities [33,34]. Efforts have been made in utilizing RHA as SCM for concrete production or as a precursor for AAMs synthesis [35]. Generally, the inclusion of RHA contributed to a refined pore structure and generated a dense microstructure, which consequently resulted in the enhancement of mechanical properties [36-45]. The influence of RHA on fresh and hardened properties of GGBS-based SCAAM has been investigated [28]. The flowability and fluidity reduced as RHA incorporation increased from $5 \%$ to $25 \%$, but the workability of the tested mixtures remained within acceptable limits. Mechanical improvement was only observed at RHA replacement of $5 \%$. Similar results were reported by Ardiantoro et al. [46], in which the mixture of RHA and fly ash was used as precursor and maximum substitution of RHA was $8.65 \%$ in terms of strength behavior. More detailed investigation is needed to optimize and promote the utilization of RHA in SCAAM.

\subsubsection{Nano Silica}

Nano silica (NS), also known as silica nanoparticles or silicon dioxide nanoparticles, is an excellent additive for the manufacture of plastics, rubber, catalyst and coating materials [47]. NS has also been utilized as effective supplementary cementitious material (SCM) in Portland cement system. NS possesses ideal pozzolanic reactivity, which can be assigned to the X-ray amorphous characteristic as well as the considerable fine particle size. 
Acceleration of hydration process and refinement of pore structure have been observed after adding NS, which consequently enhanced the mechanical properties of the obtained concrete [48-52]. Moreover, the inclusion of NS in small amounts can obviously decrease setting time and improve the mechanical strength of AAM [53,54]. Increased formation of reaction products and densified matrix structures were observed, which also contributed to improved durability properties reflecting less water absorption and reduced charge pass in a repaid $\mathrm{Cl}^{-}$penetration test [54]. SCAAM based on alkali activated FA-GGBS with varying NS content has been investigated [28]. The inclusion of NS by $1 \%$ and $2 \%$ decreased slump flow of SCAAM from $709 \mathrm{~mm}$ to $695 \mathrm{~mm}$ and $680 \mathrm{~mm}$, respectively.

\subsubsection{Ceramic Powder}

Ceramic powder $(\mathrm{CP})$ is obtained after the collection, cleaning and grinding of waste ceramic, which is mainly composed of $\mathrm{SiO}_{2}, \mathrm{Al}_{2} \mathrm{O}_{3}$ and $\mathrm{Na}_{2} \mathrm{O}$, with main crystalline phases of quartz and mullite. [55-58]. Due to the low pozzolanic reactivity and high water adsorption property, the utilization of $\mathrm{CP}$ in ordinary Portland cement (OPC) concrete production as SCM normally leads to reduced strength [57,59]. Meanwhile, geopolymer has been synthesized by Sun et al. [60] using $\mathrm{CP}$ as precursor, with obtained geopolymer showing excellent mechanical strength and thermal resistance. The mixture of CP and GGBS (CP accounts up to $80 \mathrm{wt} . \%$ ) has been used to prepare SCAAM [9], with the rheological and mechanical properties of the resulting SCAAM being characterized. The addition of CP contributes to enhance the flow and passing ability of SCAAM but causes a decrease in segregation resistance. Though the strength decreased with the increase of $\mathrm{CP}$, the tested samples achieved acceptable compressive strength.

\subsubsection{Wollastonite}

Wollastonite, a calcium inosilicate mineral, is composed of calcium and silicon oxides with small substitutions, if any, of the calcium by iron, magnesium and manganese. Geologically, it is usually formed by placing calcium rock (for example limestone, dolomite) under high temperature and pressure with the presence of fluids containing silica. Wollastonite is characterized by a unique needle-like structure, high whiteness/brightness and thermal stability, low moisture, and oil absorption [61]. Wollastonite has been used primarily in the production of ceramics and brakes, or as fillers for plastics, paints, etc. [62]. Moreover, several studies have investigated the characteristics of concrete incorporating wollastonite. Enhancements in compressive strength have been reported by Ransinchung and Kumar [63] when replacing cement by wollastonite up to $15 \%$. Higher replacement caused a decrease in both compressive and flexural strength as well as marginal variations in pull-off tests [64]. In contrast, the inclusion of wollastonite accelerated the dissolution of solid precursor and consequently contributed to increase viscosity and mechanical strength of obtained AAM [65]. SCAAM utilizing the mixture of FA, GGBS and wollastonite as precursor was prepared by Vishnu et al. [27]. Comparing with the control specimen, the synthesized SCAAM containing $10 \%$ wollastonite achieved better workability and similar strength.

\subsubsection{Water Treatment Sludge}

Water treatment sludge (WTS) is the solid waste generated from water treatment plants, mainly during the coagulation-flocculation step. In many cases, WTS can be defined as clay-based waste composing suspended aluminosilicate-rich sediments and by-products of chemical reagents [66]. WTS has been previously disposed of by landfilling, while nowadays efforts have been made to convert WTS into alternative source materials for ceramic and cement production $[67,68]$. In the regard of AAM production, different synthesis processes have been employed. Guo and Shi [69], Nimwinya et al. [70], and Waijarean et al. [71], individually synthesized AAM using WTS after calcination. The thermal treatment process not only removes organic matter present in WTS but also enhances pozzolanic reactivity of the resultant sludge. The $28 \mathrm{~d}$ compressive strength over $50 \mathrm{MPa}$ has been achieved by AAM produced using calcined WTS [69]. WTS has been used as solid precursor for AAM 
synthesis without thermal treatment [72-74]. The incorporation of non-calcined WTS may generally induce undesirable characteristics such as delayed setting time, reduced workability, and decreased mechanical strength [72]. For modification, WTS was mixed with other pozzolanic precursors or curing AAM specimens at elevated temperatures [72,74,75]. Hwang et al. [75] characterized the fresh and hardened properties of SCAAM containing up to $20 \%$ WTS. The authors reported that increasing WTS content led to reduced workability, enhanced fresh unit weight, and increased initial setting time of fresh SCAAM. Moreover, the compressive strength of hardened samples was significantly enhanced by the increase of WTS.

\subsection{Formulations of SCAAMs}

The mixture SCAAM is designed to achieve required performances in both fresh and hardened states. Though lack of design code, some of the approaches have been demonstrated as applicable in the fabrication of SCAAM. Table 1 summarizes typical SCAAM mixtures from the literature. The formulations of solid precursor and activator possess dominant roles on the workability of AAM, which will be discussed in depth in the following section. Due to the extremely alkaline conditions, subsequent degradation of superplasticizer in AAM system has been observed [76]. Hence, many effective superplasticizers from the OPC system do not work well for AAM. Meanwhile, polycarboxylate-based superplasticizers have been demonstrated in some studies showing promising performance in AAM [77-79]. The polycarboxylate-based superplasticizer has also been adopted [30,79,80]. Success in workability improvement has been achieved after adding superplasticizer, but the addition amount is much higher than in cement concrete. Further investigation to minimize the required quantity or to explore other effective chemical admixtures are needed.

Table 1. Typical SCAAM mixture proportions and properties.

\begin{tabular}{|c|c|c|c|c|c|c|c|c|c|c|}
\hline \multirow[b]{2}{*}{ Reference } & \multirow[b]{2}{*}{ Precursor } & \multirow[b]{2}{*}{ Activator } & \multirow[b]{2}{*}{ Fine Aggregate } & \multirow[b]{2}{*}{$\begin{array}{l}\text { Coarse } \\
\text { Aggregate }\end{array}$} & \multicolumn{2}{|c|}{ Slump Flow } & \multirow{2}{*}{$\begin{array}{c}\text { V-Funnel } \\
\text { (s) }\end{array}$} & \multirow{2}{*}{$\begin{array}{l}\text { L-Box } \\
\text { H2/H1 }\end{array}$} & \multicolumn{2}{|c|}{ J-Ring } \\
\hline & & & & & $\underset{(\mathrm{mm})}{\text { Spreading }}$ & T50(s) & & & $(\mathrm{mm})$ & Difference \\
\hline [9] & $\begin{array}{l}\text { Mixture of } \\
\text { GGBS and } \\
\text { ceramic tile } \\
\text { powder, } \\
484 \mathrm{~kg} / \mathrm{m}^{3}\end{array}$ & $\begin{array}{l}\text { Mixture of } \\
\text { NaOH and } \\
\text { sodium } \\
\text { silicate } \\
\text { solution, } \\
\text { activator to } \\
\text { solid } \\
\text { precursor } \\
\text { ratio of } 0.5\end{array}$ & $\begin{array}{l}\text { River sand, } \\
844 \mathrm{~kg} / \mathrm{m}^{3}\end{array}$ & $\begin{array}{c}\text { Crushed } \\
\text { granite, } \\
756 \mathrm{~kg} / \mathrm{m}^{3}\end{array}$ & $560-748.4$ & $3.0-6.0$ & $7.5-14.0$ & $0.78-0.95$ & - & $6.0-12.0$ \\
\hline [26] & $\begin{array}{l}\text { Mixture of } \\
\text { GGBS with } \\
\text { quartz } \\
\text { powder, } \\
700-800 \mathrm{~kg} / \mathrm{m}^{3}\end{array}$ & $\begin{array}{l}\text { Mixtures of } \\
\text { sodium } \\
\text { silicate with } \\
\text { NaOH, } \\
\text { solution to } \\
\text { precursor } \\
\text { ratio } 0.4-0.44\end{array}$ & $\begin{array}{l}\text { Mixture of steel } \\
\text { slag sand and } \\
\text { quartz sand, } \\
573-728 \mathrm{~kg} / \mathrm{m}^{3}\end{array}$ & $\begin{array}{l}\text { Electric arc } \\
\text { furnace slag, } \\
387-490 \mathrm{~kg} / \mathrm{m}^{3}\end{array}$ & $700-800$ & $4-5$ & $8.5-10.4$ & $0.88-0.95$ & $693-795$ & $7.8-9.7$ \\
\hline [27] & $\begin{array}{c}\text { GGBS, } \\
700-900 \mathrm{~kg} / \mathrm{m}^{3}\end{array}$ & $\begin{array}{l}\text { Mixtures of } \\
\mathrm{NaOH} \text { and } \\
\text { sodium } \\
\text { silicate } \\
\text { solutions, } \\
\text { water to } \\
\text { binder ratio } \\
\text { of } \\
0.47,0.475 \\
\text { and } 0.48\end{array}$ & $\begin{array}{c}\text { Slag sand, } \\
303-636 \mathrm{~kg} / \mathrm{m}^{3}\end{array}$ & $\begin{array}{l}\text { Electric arc } \\
\text { furnace slag, } \\
228-480 \mathrm{~kg} / \mathrm{m}^{3}\end{array}$ & $685-720$ & $3.7-4.8$ & $8.5-11.0$ & $0.86-0.96$ & $670-717$ & $5.0-7.0$ \\
\hline [30] & $\begin{array}{c}\text { Mixture of } \\
\text { GGBS and } \\
\text { FA, } \\
450 \mathrm{~kg} / \mathrm{m}^{3}\end{array}$ & $\begin{array}{l}\text { Sodium } \\
\text { silicate and } \\
\text { sodium } \\
\text { hydroxide } \\
\text { solutions, } \\
\text { activator to } \\
\text { precursor } 0.5\end{array}$ & $\begin{array}{c}\text { Crushed } \\
\text { limestone, } \\
859.7-865.6 \mathrm{~kg} / \mathrm{m}^{3}\end{array}$ & $\begin{array}{c}\text { Crushed } \\
\text { limestone, } \\
737.8-742.8 \mathrm{~kg} / \mathrm{m}^{3}\end{array}$ & $679.5-709.0$ & $2.8-3.6$ & $10.8-16.6$ & $0.88-0.96$ & - & - \\
\hline [80] & $\begin{array}{l}\text { Mixture of } \\
\text { GGBS with } \\
\text { RHA, } \\
500 \mathrm{~kg} / \mathrm{m}^{3}\end{array}$ & $\begin{array}{l}\text { Mixture of } \\
\text { sodium } \\
\text { silicate } \\
\text { solution with } \\
\text { NaOH }\end{array}$ & $\begin{array}{l}\text { River sand, } \\
1100 \mathrm{~kg} / \mathrm{m}^{3}\end{array}$ & $\begin{array}{l}\text { Crushed } \\
\text { limestone, } \\
785 \mathrm{~kg} / \mathrm{m}^{3}\end{array}$ & $655-710$ & $4.0-5.5$ & $8-13$ & $0.8-0.95$ & - & $6-9$ \\
\hline
\end{tabular}


Table 1. Cont.

\begin{tabular}{|c|c|c|c|c|c|c|c|c|c|c|}
\hline \multirow[b]{2}{*}{ Reference } & \multirow[b]{2}{*}{ Precursor } & \multirow[b]{2}{*}{ Activator } & \multirow[b]{2}{*}{ Fine Aggregate } & \multirow{2}{*}{$\begin{array}{c}\text { Coarse } \\
\text { Aggregate }\end{array}$} & \multicolumn{2}{|c|}{ Slump Flow } & \multirow{2}{*}{$\begin{array}{c}\text { V-Funnel } \\
\text { (s) }\end{array}$} & \multirow{2}{*}{$\begin{array}{l}\text { L-Box } \\
\text { H2/H1 }\end{array}$} & \multicolumn{2}{|c|}{ J-Ring } \\
\hline & & & & & $\underset{(\mathrm{mm})}{\text { Spreading }}$ & T50(s) & & & $(\mathrm{mm})$ & Difference \\
\hline [81] & $\begin{array}{l}\text { Mixture of } \\
\text { FA and GGBS, } \\
480-655 \mathrm{~kg} / \mathrm{m}^{3}\end{array}$ & $\begin{array}{l}\text { Mixture of } \\
\text { NaOH and } \\
\text { sodium } \\
\text { silicate } \\
\text { solution, } \\
\text { activator to } \\
\text { precursor } \\
\text { ratio of } 0.1 \\
0.3 \text { and } 0.5\end{array}$ & - & - & $545.7-706.5$ & $3.0-14.03$ & $9.0-19.0$ & $0.38-0.88$ & - & - \\
\hline [82] & $\begin{array}{c}\text { Mixture of } \\
\text { GGBS and } \\
\text { FA, } \\
484 \mathrm{~kg} / \mathrm{m}^{3}\end{array}$ & $\begin{array}{c}\text { Solution with } \\
\mathrm{SiO}_{2} \text {-to- } \mathrm{Na}_{2} \mathrm{O} \\
\text { ratio of } 1.02, \\
\text { activator to } \\
\text { precursor } \\
\text { ratio of } 0.5\end{array}$ & $\begin{array}{l}\text { River sand, } \\
844 \mathrm{~kg} / \mathrm{m}^{3}\end{array}$ & $\begin{array}{l}\text { Crushed } \\
\text { limestone, } \\
756 \mathrm{~kg} / \mathrm{m}^{3}\end{array}$ & $560.6-720.2$ & $3.5-6.0$ & $8.5-14.0$ & $0.78-0.92$ & - & $6.0-12.0$ \\
\hline [83] & $\begin{array}{c}\text { GGBS, } \\
475 \mathrm{~kg} / \mathrm{m}^{3}\end{array}$ & $\begin{array}{l}\text { Mixture of } \\
\text { NaOH with } \\
\text { sodium } \\
\text { metasilicate, } \\
\text { activator to } \\
\text { precursor } \\
\text { ratio of } 0.43\end{array}$ & $\begin{array}{l}\text { Mixture of } \\
\text { spent garnet } \\
\text { with sand, } \\
950 \mathrm{~kg} / \mathrm{m}^{3}\end{array}$ & - & $671-700$ & $3.5-5.5$ & $6.5-12.0$ & $0.91-0.97$ & - & - \\
\hline
\end{tabular}

SCAAM is normally of higher paste to aggregate and fine aggregate to coarse aggregate ratios. The adding sequence of components, mixing time and even mixer type affect the homogeneity and uniformity of obtained mixture. Based on the literature cited in this work, fine and coarse aggregates were firstly mixed followed by the addition of solid precursor. Activator, superplasticizer, and extra water (if any) were then added. The whole mixing time ranges from 6 to 9 min or even longer, depending on initial mix design, required property and mixer. Afterwards, the homogeneous mixture was subjected to fresh state characterization or casted and cured for hardened property tests.

\section{Property of Fresh SCAAMs}

Fresh properties of typical SCAAMs from the literature are listed in Table 1. It should be mentioned that GGBS, FA and other precursors/additives of different physicochemical characteristics were used. The mixture proportions were also described in various ways, including activator/solid ratio, $\mathrm{Na}_{2} \mathrm{O}$ /binder ratio, activator ratio, etc. To facilitate and simplify the comparison of data from different sources, recalculation was conducted with the following principles:

(1) alkaline solution is composed of solid activator plus water, i.e., in sodium silicate solution is composed of $\mathrm{SiO}_{2}+\mathrm{Na}_{2} \mathrm{O}+\mathrm{H}_{2} \mathrm{O}, \mathrm{NaOH}$ solution is composed of $\mathrm{Na}_{2} \mathrm{O}+\mathrm{H}_{2} \mathrm{O}$;

(2) binder is the sum of precursor and solid activator and additives (RHA, NS, etc., if any);

(3) total water is the sum of water from alkaline solution and extra water added.

For example, an SCAAM is synthesized using the mixture of GGBS $\left(\mathrm{SiO}_{2}: 30.8 \mathrm{wt} . \%\right)$ and $\mathrm{FA}\left(\mathrm{SiO}_{2}: 57.2 \mathrm{wt} . \%\right)$, the content of precursor mixture is $484 \mathrm{~kg} / \mathrm{m}^{3}$, with mass ratio of GGBS to FA being 7:3. $\mathrm{NaOH}$ solution with concentration of $2 \mathrm{~mol} / \mathrm{L}$ and analytical sodium silicate solution (Modulus: 2.07, $\mathrm{SiO}_{2}: 29.5 \mathrm{wt} . \%, \mathrm{Na}_{2} \mathrm{O}: 14.70 \mathrm{wt} . \%, \mathrm{H}_{2} \mathrm{O}: 55.80 \mathrm{wt} . \%$ ) were used. Mass ratio of sodium silicate to $\mathrm{NaOH}$ solution was 0.75 , mixed solution was cooled down for $24 \mathrm{~h}$ before being used. For the concrete preparation, river sand and crushed gravel were used. The solution-to-solid ratio, extra water, fine and coarse aggregate content was $0.5,185.9 \mathrm{~kg} / \mathrm{m}^{3}, 844 \mathrm{~kg} / \mathrm{m}^{3}$ and $756 \mathrm{~kg} / \mathrm{m}^{3}$, respectively.

In this case, for $1 \mathrm{~m}^{3}$ of SCAAM concrete,

mass of mixed solution: $\mathrm{m}_{\text {solution }}=484 \mathrm{~kg} / \mathrm{m}^{3} \times 0.5 \times 1 \mathrm{~m}^{3}=242 \mathrm{~kg}$;

mass of solidum silicate solution: $\mathrm{m}_{\text {silicate }}=242 \mathrm{~kg} \times 0.429=103.71 \mathrm{~kg}$;

mass of $\mathrm{NaOH}$ solution: $\mathrm{m}_{\mathrm{NaOH}}=242 \mathrm{~kg} \times 0.571=138.29 \mathrm{~kg}$;

mass of $\mathrm{SiO}_{2}$ in sodium silicate solution: $\mathrm{m}_{(\mathrm{SiO} 2 \text {-solution })}=103.71 \mathrm{~kg} \times 0.295=30.60 \mathrm{~kg}$;

mass of $\mathrm{SiO}_{2}$ in GGBS: $\mathrm{m}_{(\mathrm{SiO}-\mathrm{GGBS})}=484 \mathrm{~kg} \times 0 . \times 0.308=104.35 \mathrm{~kg}$;

mass of $\mathrm{SiO}_{2}$ in $\mathrm{FA}: \mathrm{m}_{(\mathrm{SiO} 2-\mathrm{FA})}=484 \mathrm{~kg} \times 0.3 \times 0.572=83.05 \mathrm{~kg}$; 
mass of $\mathrm{Na}_{2} \mathrm{O}$ in sodium silicate solution: $\mathrm{m}_{(\mathrm{Na} 2 \mathrm{O}-\mathrm{SS})}=103.71 \mathrm{~kg} \times 0.147=15.25 \mathrm{~kg}$; mass of $\mathrm{Na}_{2} \mathrm{O}$ in $\mathrm{NaOH}$ solution: $\mathrm{m}_{(\mathrm{Na} 2 \mathrm{O}-\mathrm{SH})}=(138.29 \mathrm{~kg} \times 0.74 \times 62) /(40 \times 2)=79.31 \mathrm{~kg}$; mass of binder: $m_{\text {binder }}=484 \mathrm{~kg}+30.60 \mathrm{~kg}+15.25 \mathrm{~kg}+79.31 \mathrm{~kg}=609.16 \mathrm{~kg}$;

mass of total water: $\mathrm{m}_{\text {water }}=103.71 \mathrm{~kg} \times 0.558+138.29 \mathrm{~kg}-79.31 \mathrm{~kg}+185.9 \mathrm{~kg}=302.75 \mathrm{~kg}$; water-to-binder ratio: $\mathrm{r}=\mathrm{m}_{\text {water }} / \mathrm{m}_{\text {binder }}=(302.75 \mathrm{~kg}) /(609.16 \mathrm{~kg})=0.497$;

content of $\mathrm{SiO}_{2}$ in binder: $\left.\mathrm{w}_{\mathrm{SiO} 2}=\left(\mathrm{m}_{(\mathrm{SiO} 2 \text {-solution })}+\mathrm{m}_{(\mathrm{SiO} 2-\mathrm{GGBS})}+\mathrm{m}_{(\mathrm{SiO} 2-\mathrm{FA}}\right)\right) / \mathrm{m}_{\text {binder }}$ $\times 100 \%=35.79 \%$.

After this kind of calculation, the mixtures from different literature can be directly compared and the relationship between slump flow value and mixture proportion is plotted in Figure 1.

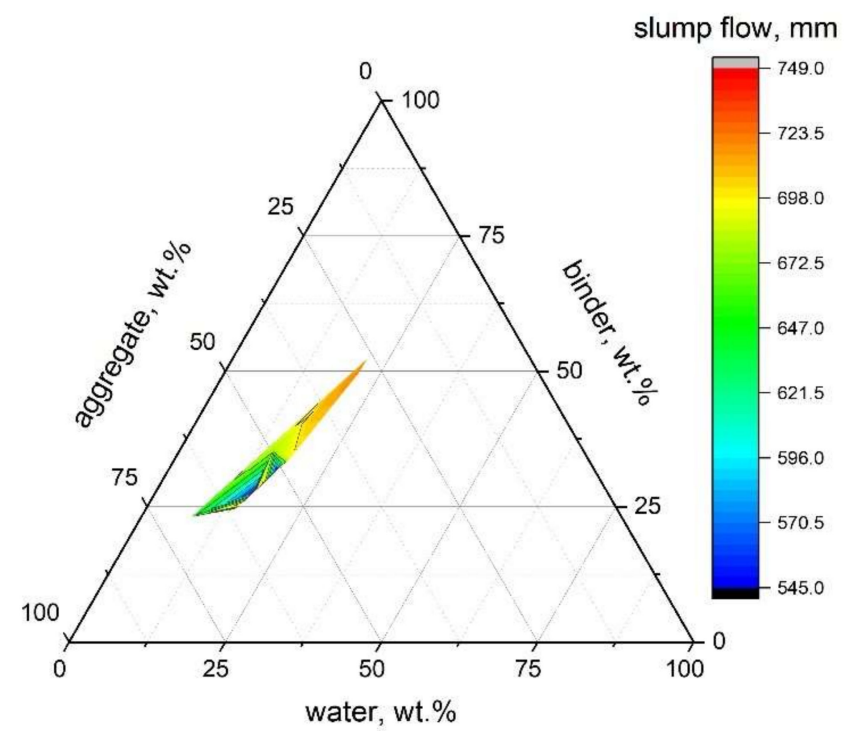

Figure 1. Relationship between slump flow and mixture proportion (data from $[9,27,30,81,82,84,85]$ ).

As abovementioned, water content is one of the key factors determining the fresh properties of SCAAM. In [86], the slump flow of SCAAM increased close to linearly from $650 \mathrm{~mm}$ to $825 \mathrm{~mm}$ as the water/binder ratio increased from 0.4 to 0.5 , which all exceeded the spread values as per ENFARC and the Australia code for SCC [87]. The water/binder ratio is located in a similar range to conventional AAMs. The much higher slump range can be related to the proportional binder design and the aggregate gradation. SCC normally has a higher paste-to-aggregate ratio than conventional concrete, and the volumetric content of coarse aggregate is less than 50\% [2,6]. Alkaline solution initially contains a considerable amount of water, and enhancing the solution/solid ratio can, as a consequence, increase the total water content. Meanwhile, increased activator dosage plays a significant role in accelerating setting and hardening of resultant SCAAMs. Thus, alkaline activator dosage has fluctuating effects on the workability of SCAAMs, and in some cases reduces workability [88]. As per the concentration of $\mathrm{NaOH}$ solution, a drop in workability induced by concentration increase has been reported $[88,89]$. Saini and Vattipalli [89] observed workability decrease in GGBS-based SCAAM when the $\mathrm{NaOH}$ concentration varied between $10 \mathrm{~mol} / \mathrm{L}$ and $16 \mathrm{~mol} / \mathrm{L}$. Nagaraj and Venkatesh Babu stated that mixtures with $\mathrm{NaOH}$ concentration above $12 \mathrm{~mol} / \mathrm{L}$ failed to meet the workability requirements for SCC [88].

It can be inferred from the published results (shown in Figure 1) that workability improves with the replacement of GGBS by FA [81,84,85]. Huseien and Shah [85] reported that replacing 70\% GGBS by FA resulted in slump increase of $70 \mathrm{~mm}$. The slump flow value of $100 \%$ FA-based SCAAM has been reported as 1.25 and 1.03 times its counterparts with $50 \%$ GGBS and 100\% GGBS, respectively [81]. A similar conclusion can also be drawn for V-funnel, L-box, and J-ring tests [84]. GGBS is generally of higher reactivity than FA, which might correspond to momentous acceleration in alkaline activation, hardening and setting. 
In addition, unlike the angular shaped particles of GGBS, the spherical particle of FA also contributes to improve workability [81].

\section{Property of Hardened SCAAMs}

\subsection{Compressive Strength}

Reactivity of solid precursors has a significant influence on the mechanical properties of resultant SCAAMs. Specimens prepared using FA were impossible to demold after $3 \mathrm{~d}$ curing at ambient condition because of low reactivity [28]. In contrast, GGBS-based SCAAM achieved $3 \mathrm{~d}$ compressive strength of $34.76 \mathrm{MPa}$, accounting for $84 \%$ of $28 \mathrm{~d}$ strength [28]. Studies show that the activation energy of the FA system is 1.5 times that of the GGBS system or even higher [31,90,91], indicating that the FA system must overcome a higher energy barrier than GGBS system to initiate reaction. Solutions to lower the activation energy include proportional mix-design and elevated temperature curing. Combining FA with GGBS is a powerful way to improve the mechanical behaviors of SCAAMs containing FA. According to Nagaraj and Venkatesh Babu [81], replacing 50\% of FA by GGBS can individually enhance the $7 \mathrm{~d}$ and $90 \mathrm{~d}$ compressive strength by 3.34-5.58 times and 3.64-5.23 times, respectively. Apart from the improved reaction kinetic after incorporating GGBS, the modification of microstructure was also observed, which will be discussed in Section 5.2 [81]. Another way in terms of mix-design is modifying activator utilization. It has been clearly observed that the strength of SCAAMs increased with an increase in activator molarity [88]. Low strength has been attained by samples prepared with solidum hydroxide solution lower than $4 \mathrm{M}$. A high activator-to-solid ratio would also have some negative influence on strength $[88,92]$. As discussed above, considerable content of water was incorporated into SCAAM matrixes of high activator-to-solid ratio, which would lead to a porosity increase and mechanical deterioration.

Patel and Shah [28] have stated that the dissolution of Si and Al in FA particles is slow at ambient temperature. Curing at elevated temperature is of a benefit for the formation of gels and the following polymerization and condensation processes. The mechanism behind this phenomenon has been investigated by Sun and Vollpracht [31]. The alkaliactivated FA system is more temperature dependent, as raising the reaction temperature can significantly enhance cumulative isothermal heat release. Moreover, the calorimetric response was converted from single-peak into multiple-peak, indicating the occurrence of multiple chemical reactions and structure transformation [31]. Supporting the statement of Patel and Shah [28], the $3 \mathrm{~d}$ compressive strength of obtained samples can be increased 8.8 -fold after elevating the first $12 \mathrm{~h}$ curing time from $20^{\circ} \mathrm{C}$ to $60^{\circ} \mathrm{C}$, while extending duration from $12 \mathrm{~h}$ to $24 \mathrm{~h}$ can further improve the mechanical performance 1.5-fold [93].

It should be mentioned that data from the literature can hardly be directly compared since mix design and synthesis procedure differ widely. After revisiting the literature, a calculation was conducted to normalize the binder composition. The results are shown in Figure 2, which depicts the pseudo-ternary plot relating the effects of the main components to the $28 \mathrm{~d}$ compressive strength of resultant SCAAMs. The calculation was based on the same principles as Section 5. In particular, the $\mathrm{Na}_{2} \mathrm{Oeq}$ is calculated following:

$$
\mathrm{Na}_{2} \mathrm{O}_{\text {eq }}=\left(\mathrm{m}\left(\mathrm{Na}_{2} \mathrm{O}\right)+\mathrm{m}\left(\mathrm{K}_{2} \mathrm{O}\right) / 94.2 \times 62+\mathrm{n}(\mathrm{CaO}) / 56.1 \times 62\right) / \text { mbinder } \times 100 \%
$$

in which the contents of $\mathrm{K}_{2} \mathrm{O}$ and $\mathrm{CaO}$ are included on the basis of molar equivalency and cation charge. The authors are highly aware that this kind of calculation may underestimate the influence of $\mathrm{CaO}$, especially for SCAAMs with high calcium. The role of calcium differs from sodium/potassium in alkali activation process. As the low-calcium is predominantly composed of alkali aluminosilicate gel (N-A-S- $(\mathrm{H})$ ), in which the alkali cations balance the negative charge caused by substitution of silicon by aluminum [17]. Meanwhile, the calcium aluminosilicate gel (C-A-S-H) is detected as the key reaction product, which is to some extent regarded as aluminum substituted calcium silicate gel (C-S-H). The C-A-S-H gel is reported to possess a microstructure similar to tobermorite, with calcium cations locating in the interlayer region of tetrahedrally coordinated silicate chains [17]. But this calculation 
can somehow facilitate the comparison of independent studies and afford insights into the contribution of main components to mechanical performance of obtained products.

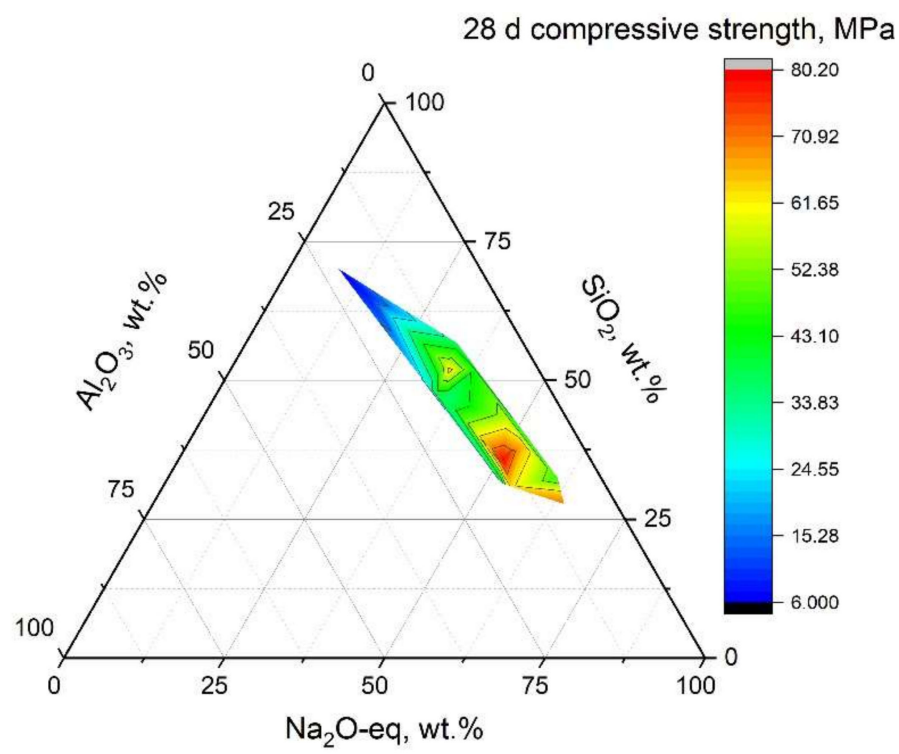

Figure 2. Pseudo-ternary plot of $28 \mathrm{~d}$ compressive strength with binder composition (data from $[9,27,30,81,82,94])$.

It can then be inferred that the increase of $\mathrm{Na}_{2} \mathrm{Oeq}$ in binder generally leads to an improvement of compressive strength. Multi-linear regression has been made for $28 \mathrm{~d}$ compressive strength and $\mathrm{Na}_{2} \mathrm{O}$ dosage was found as the key positive parameter in the correlation [27]. High $\mathrm{Na}_{2} \mathrm{Oeq}$ content suggests high alkalinity after mixing with water, which consequently contributes to the dissolution of aluminosilicate components and the formation of strength-giving products.

It has been stated that AAMs can be produced with a Si/ $\mathrm{Al}$ ratio ranging from 0.5 to 300 [39]. $\mathrm{Xu}$ and Deventer [95] observed that a correlation is present between the $\mathrm{Si} / \mathrm{Al}$ ratio in mixture and mechanical strength of AAMs. Thus, a feasible Si-Al proportion is required to obtain materials with interesting properties. Based on the chemistry of zeolite, Davidovits recommended a $\mathrm{Si} / \mathrm{Al}$ ratio of $1.75-2.25\left(\mathrm{SiO}_{2} / \mathrm{Al}_{2} \mathrm{O}_{3}\right.$ ratio 3.5-4.5) for metakaolin based AAMs [96]. This is supported by Duxson et al. in a which $\mathrm{Si} / \mathrm{Al}=1.9$ was found to achieve the optimal strength [97]. While Fletcher et al. [39] reported that $\mathrm{NaOH}$ activated metakaolin samples possessed the maximum strength at $\mathrm{Si} / \mathrm{Al}=8$. This can be related to the content difference of reactive $\mathrm{Si}$ and $\mathrm{Al}$ in the original prime material. Based on extensive investigation on several types of FA, Fernandez-Jimenez et al. [98] concluded that a $\mathrm{Si} / \mathrm{Al}$ ratio of reactive phase in the range of $1.42-2.38$ is suggested. Provis et al. extended the statistic to frequently used precursor systems and summarized that product formed at compositional range of $1<\mathrm{Si} / \mathrm{Al}<5$ would be suited to general construction applications [18]. Mixtures with superior strength in Figure 2 are with $\mathrm{Si} / \mathrm{Al}$ ratio locating in this range.

\subsection{Microstructure}

The microstructure of SCAAMs has been intensively characterized using SEM. Specimens produced using GGBS showed a dense and homogeneous microstructure, with little unreacted particles [82]. Voids and cracks can also be observed, which might be related to air bubbles introduced during sample preparation, spaces induced by water evaporation, repaid setting and self-drying of the sample, shrinkage of reaction products, and load application during test $[28,99,100]$. In comparison, the structure of SCAAMs containing FA is relative loose and porous (Figure 3). Voids, cracks, and unreacted particles can be clearly seen. This can be partially ascribed to the low reactivity of FA, with limited gels to 
bridge unreacted particles. Moreover, the spherical particle of FA might also be responsible. As depicted by Fernandez-Jimenez et al. [101], dissolution of FA particles initiated from the contact area with activator, leads to exposure of the inner sides or the smaller particles initially entrapped by larger ones. With the diffusion of alkaline solution, chemical attack then takes place in bilateral directions, i.e., from outside in and from inside out. Reaction products are simultaneously formed, covering unreacted parts as a crust and hindering further reaction.
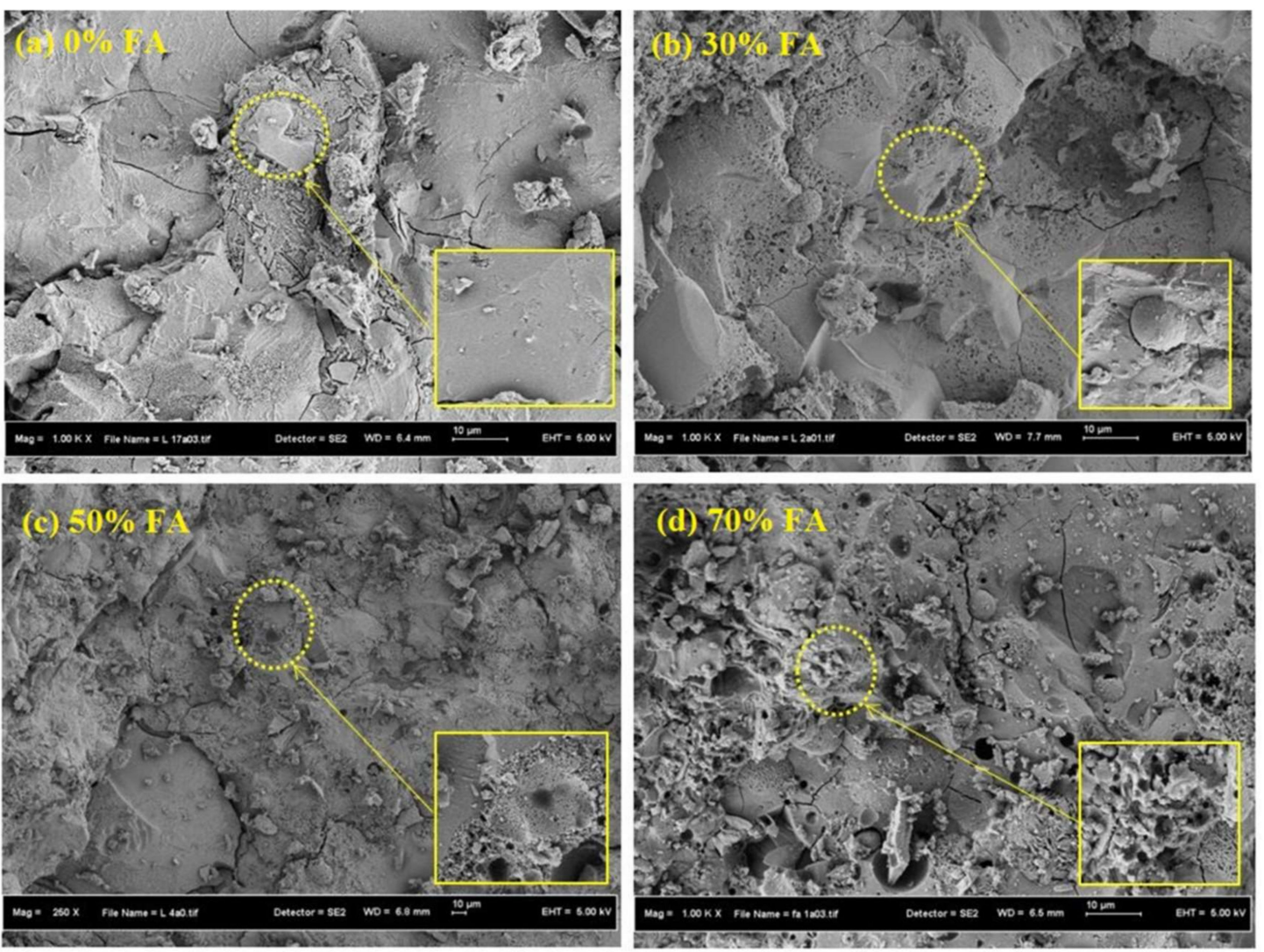

Figure 3. Microstructure of GGBS-based SCAAMs with (a) $0 \%$, (b) $30 \%$, (c) $50 \%$ and (d) $70 \%$ FA [82].

Reducing the FA content from $70 \%$ to $50 \%$ and $30 \%$, meant that the numbers of cracks, pore, unreacted particles and unevenness clearly dropped (Figure 3). This affirmed that increasing FA content can result in a high degree of porosity and poor morphology, which might be responsible for the undesired mechanical performance of obtained SCAAMs. Microstructure modification was observed after adding fine particles. Relatively fewer voids and cracks have been detected from samples containing NS or RHA [28,101]. The fine particles can not only fill in voids or cracks but also accelerate formation of reaction products [28]. Patel and Shah stated that the $\mathrm{SiO}_{2}$ in nano particles can form siloxo chains (Si-O-Si), firmly reducing the gaps among reaction products and bonding particles. All these are beneficial for generating a dense structure.

\subsection{Water Absorption}

The water absorption capacity of hardened matrix depends on size distribution and continuity of pores; thus, this characterization can provide an idea about pores present inside. Values of $2.4-3.5 \%$ and $2.1-3.4 \%$ were obtained by Manjunath et al. for GGBS-based SCAAMS with different mixtures $[26,27]$. These values are marginally lower than conventional AAM concrete and can be classified as good concrete category [102,103]. Low water absorption suggests the produced SCAAMS are potentially durable and can perform well in aggressive conditions. The water adsorption property can be significantly affected by mixture proportion. The water absorption has been observed to increase from $6.6 \%$ to 
$9.8 \%$ when replacing GGBS by FA from $0 \%$ to $70 \%$ [82]. This is attributed to the porosity increase caused by a boost in unreacted FA particles. Dener et al. [80] studied the influence of aggregate, in which pumice was used as lightweight aggregate. It was reported that the increasing pumice aggregate directly enhanced the water absorption values. The values for mixtures with $60 \%$ pumice aggregate were located in the range of $17.96-18.57 \%$, which were increased to $20.71-22.46 \%$ when $80 \%$ pumice aggregate were used.

The water absorption rate has been investigated by weighing the absorbed water quantity in a time scale of up to $360 \mathrm{~min}$ [28]. The values were at a range of $0.069-0.136 \mathrm{~mm} / \sqrt{ } \mathrm{min}$, with the maximum value being observed for FA-based samples. Specimens containing GGBS generally achieved lower absorption rate and addition can further modify the absorption behavior. Mixing 5\% RHA with GGBS contributed to a reduce in the absorption rate to $0.069 \mathrm{~mm} / \sqrt{ } \mathrm{min}$. This once again supports the above statements about the structurerefining effect of fine additives.

Practices were developed by plotting water absorption values with corresponding compressive strength, and the results are illustrated in Figure 4. Water absorption decreases with an increase of compressive strength because of denser microstructure and reduced porosity. A close to linear relationship can be inferred from these data, which is similar to OPC concrete and conventional AAMs [104].

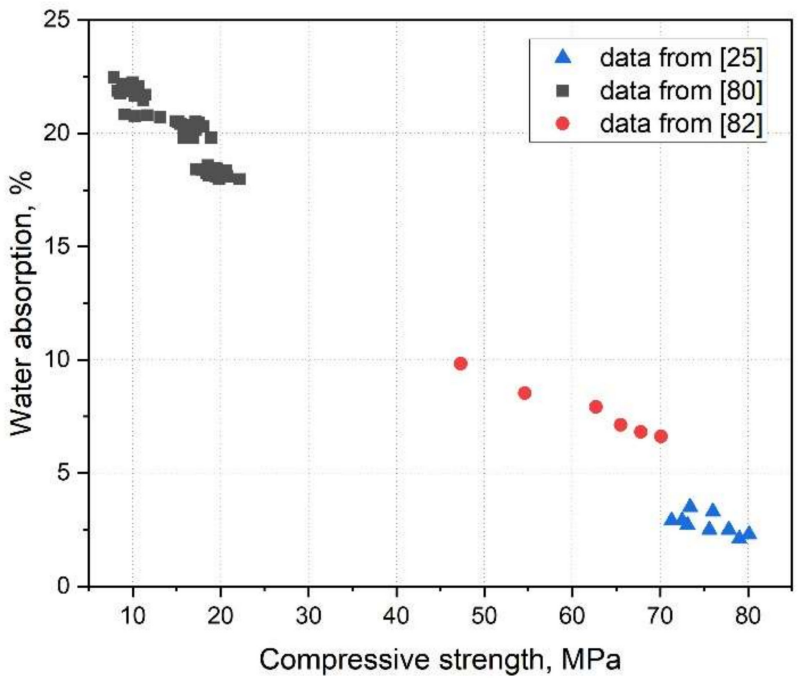

Figure 4. Correlations of water absorption with compressive strength (data from [27,80,82]).

\subsection{Acid and Sulfate Resistance}

As construction materials, SCAAMs might be used at field sites with varying geochemical parameters. Characterizing the durability over acidic and sulfate condition is fundamental in tailoring potential field applications. The corresponding mass and strength loss has been reported as $2.86-7.74 \%$ and $8.76-24.83 \%$ [81], for which the acid concentration was $3 \%(\mathrm{pH}=3)$ and immersion duration was 90 days. Similar values have been reported under comparable testing conditions but using specimens of varied activator concentrations and adoptions [88]. In comparison with OPC concretes, SCAAMs exhibited better acidic and sulfate resistance with lower mass and strength loss. In the OPC system, degradation of $\mathrm{Ca}(\mathrm{OH})_{2}$ forming expansive $\mathrm{CaSO}_{4}$ leads to softening and scaling, causing severe deterioration of the matrix [105]. In contrast, the cross-linked aluminosilicate gels of AAMs possess superior resistance to acid attack. Deterioration extent also depends on exposure conditions. By immersing GGBS-based SCAAM in 10\% $\mathrm{H}_{2} \mathrm{SO}_{4}$ solution for 12 months, weight and strength loss of $2.2 \%$ and $74 \%$ were detected, respectively [9]. Thus, increasing acid concentration and exposure duration would result in more severe damage.

Optimizing mixture composition can effectively enhance the resistance of obtained SCAAMs. The influence of precursor and activator have been investigated $[81,88]$. Increasing $\mathrm{NaOH}$ concentration from $2 \mathrm{~mol} / \mathrm{L}$ to $12 \mathrm{~mol} / \mathrm{L}$ can obviously reduce the mass and 
strength loss, while changes in the $\mathrm{NaOH}$ /sodium silicate ratio behaved on the contrary. In the studied range of $2-4.5$, a higher $\mathrm{NaOH}$ / sodium silicate ratio caused more considerable mass and strength loss. In terms of binder composition, the strength loss ratio of FA-based samples was about two times that of the GGBS-based samples, while the mass loss behaved in an opposite way. An interesting study conducted by Huseien et al. [9] illustrated that the addition of CP can improve the acid resistance of GGBS-based SCAAM (Figure 5). Both the mass and strength loss can be gradually reduced with the increase of CP from $0-80 \%$. In comparison with the control sample, mass and strength loss of mixture with $80 \% \mathrm{CP}$ was decreased from $2.2 \%$ to $0.39 \%$ and from $74 \%$ to $13.3 \%$, respectively. The enhancement in acid resistance was result of the reduction in the free calcium component [9]. All of these bring new insights into the mix-design of SCAAMs with excellent acid resistance.

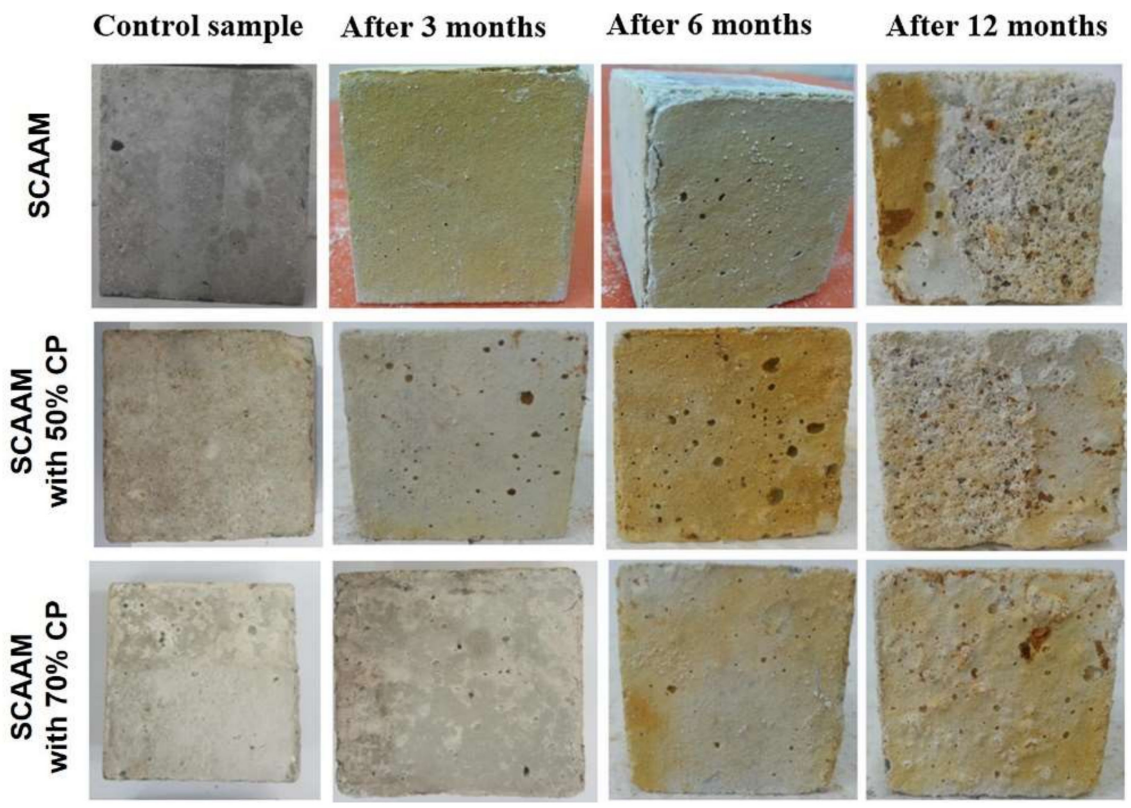

Figure 5. Photos of SCAAMs after acidic exposure (adapted from [9]).

Similar to the trend observed in acidic conditions is the mass and strength decrease after immersion in sulfate solution. The decrease scale was determined by mixture composition, sulfate concentration and exposure period. A strength drop of 3.6-4.2\%, 8.4-9.3\%, and 5.6-6.4\% was found for GGBS, FA and GGBS-FA based SCAAMs, respectively [81,88]. The corresponding mass reduction can be 1.8-2.1\%, 3.5-3.7\%, 2.4-2.9\%. The deterioration was mainly induced by formation of calcium sulfate dehydrate, which caused expansion and cracking of the matrix. A sample with low, or even free of, $\mathrm{Ca}(\mathrm{OH})_{2}$ normally showed good sulfate resistance. This is the case of better resistance of AAMs than OPC concretes. In addition, a compact structure is essential for sulfate resistance, since the inner pore structure provides diffusion pathway for sulfate ions.

\section{Other Properties}

\subsection{Impact Resistance}

Impact resistance has been characterized by a drop-weight test following ACI Committee 544 recommendations [101]. During the test, a drop hammer from a certain height is periodically impacted to the middle of the specimen. Numbers to cause failure were documented and used to calculate impact energy according to

$$
\mathrm{E}_{\mathrm{imp}}=\mathrm{N} \times \mathrm{m} \times \mathrm{g} \times \mathrm{h}
$$

where $\mathrm{E}_{\mathrm{imp}}$, impact energy, in J; N, drop numbers; $\mathrm{m}$, mass of drop hammer, in $\mathrm{kg}$; $\mathrm{g}$, gravitational acceleration, $9.81 \mathrm{~m} / \mathrm{s}^{2} ; \mathrm{h}$, releasing height of drop hammer, in $\mathrm{cm}$. 
The GGBS-based SCAAM achieved adequate impact energy comparing with OPC concrete [106]. Incorporating steel fiber can significantly enhance the impact resistance (Figure 6). Impact energy of samples with $0.5 \%$ and $1 \%$ short steel fiber (Keremix $30 / 40$ ) were 5 and 20.5 times of the control. The enhancement was further improved by using long steel fiber (Dramix 60/80). This can be related to the higher friction/adherence of long steel fiber with matrix. Similar phenomena were observed from OPC concrete system [107]. When nanosilica was put into the mixture, the impact energy for mixtures with and without steel fibers can be further enhanced by 1.3-3.5 times [101]. The enhancement was attributed to the improvement in microstructure, especially reduced porosity and modified interfacial transition zone, which affect fracture propagation directly [108].

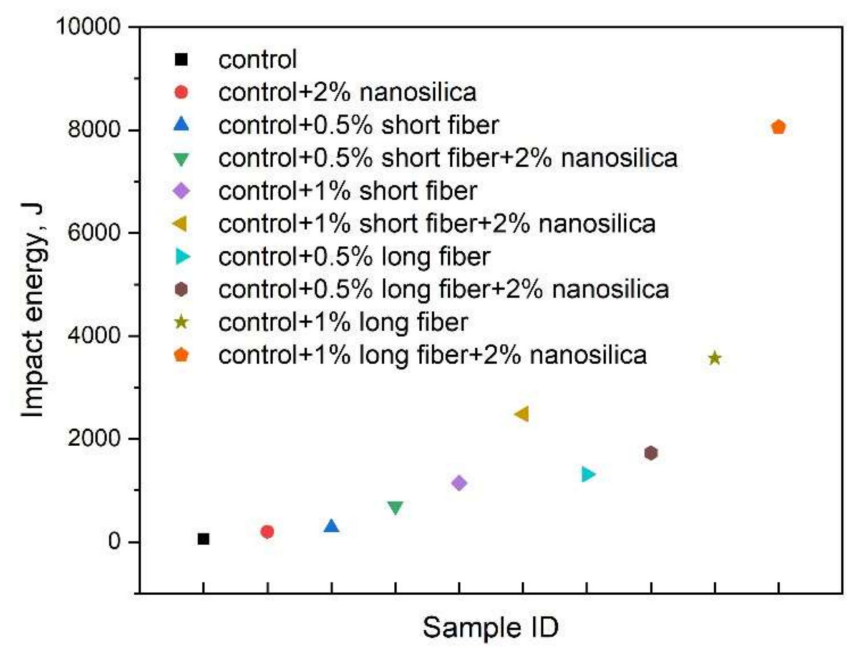

Figure 6. Impact energy of SCAAM samples (reproduced from [101]).

\subsection{Interface Shear Strength}

Interfacial shear bond strength of SCAAMs has been characterized and compared with self-compacting OPC concrete [109]. Both conventional and modified push-off test (push-off test with normal load over shear interface) were considered. Schematic diagrams and photos of the tests are shown in Figure 7, the details about experimental procedure are referred to [109] and will not be repeated herein.

(a)

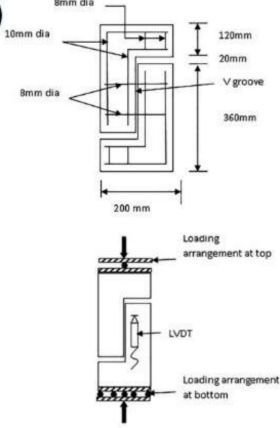

(b)

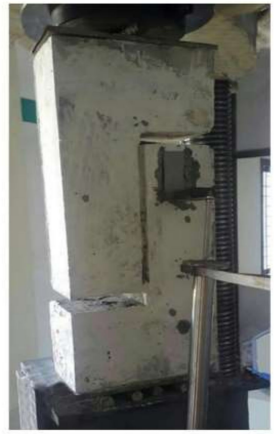

(c)

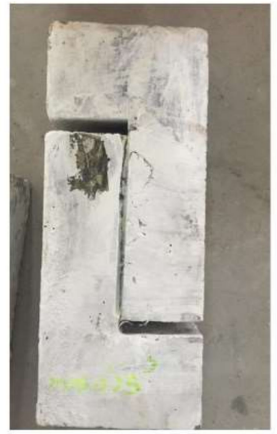

(d)

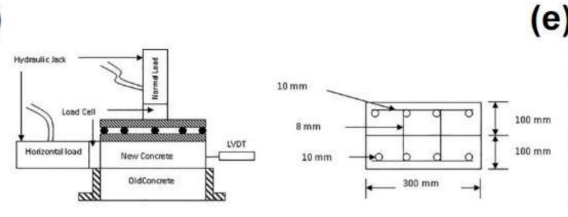

(e)

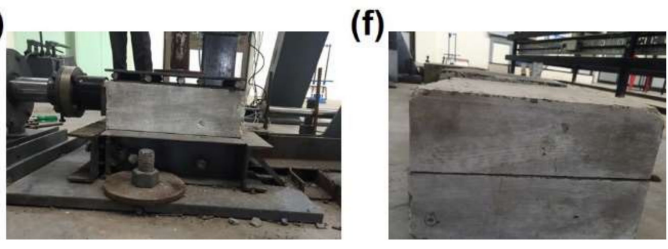

Figure 7. Schematic diagrams and photos of push-off test $((\mathbf{a}-\mathbf{c})$ : conventional push-off test; (d-f): modified push-off test. (b) and (e) before test, (c) and (f) after test) [109]. 
After the conventional push-off test, failure was observed in weak zones because of interface shear and slip (Figure 7). In particular, spalling can be seen the jointing of old and new concretes, which is the region of stress concentration [109]. The ultimate load and corresponding slip were plotted and illustrated as Figure 8, with the highest and lowest interfacial shear stress being achieved by SCAAM-SCAAM samples cast monolithically and SCC-SCAAM specimens produced under cold joint condition, respectively. As stated, stress was directly taken by concrete covering reinforcement and the debonding of concrete to steel resulted in sudden failure of monolithically casted samples. In contrast, the substrate of specimens produced under cold joint condition or laid over hardened concrete can provide enough strength to clamp reinforcement and to stay intact with surrounding concretes. Failure in this case is experienced in stress affecting reinforcement, which causes a well-defined yield plateau as shown in Figure 8 [109]. A similar trend can be inferred in the push-off test scenario of normal load applied over shear interface, in which SCAAM cold joint specimens exhibited higher interface stress than counterparts. All the results demonstrated that SCAAMs possessed better properties than SCC and can be used in concrete repair/rehabilitation.

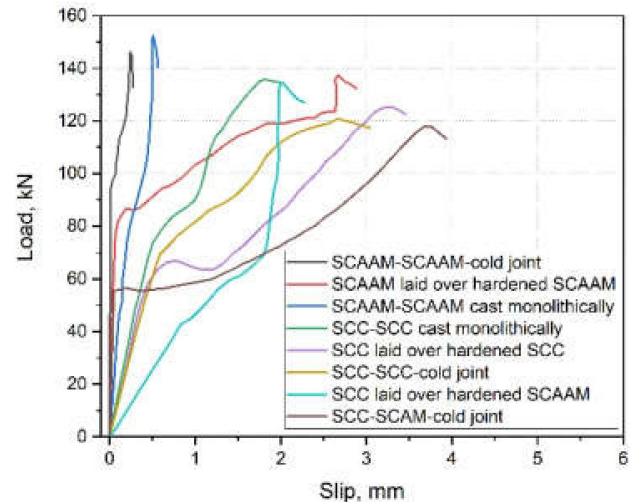

(a)

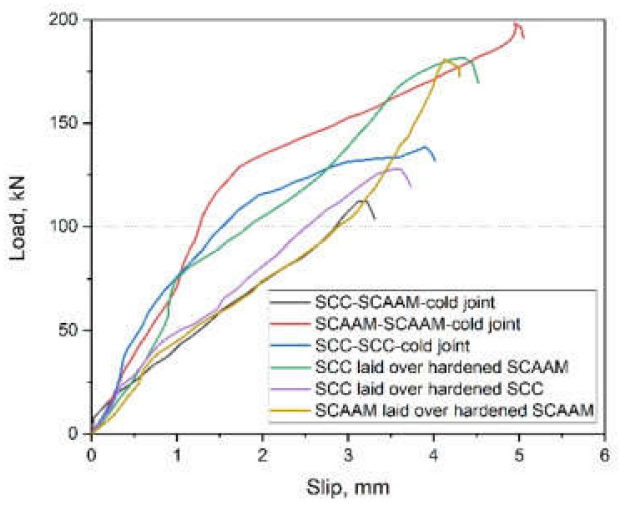

(b)

Figure 8. Correlation of load and slip in conventional (a) and modified (b) push-off test [109].

\section{Challenges and Perspectives}

SCAAMs possess excellent engineering properties and are finding potential applications in civil construction sites. Considering that the manufacture and characterization of SCAAMs are still in laboratory, challenges in mixture design and durability analysis should be addressed to promote the understanding and application of SCAAMs.

Mixture design is a vital procedure for production of concrete materials. The current fabrication of SCAAMs is mainly based on the so called "empirical design method", in which empirical data of the water-binder ratio, aggregate content, etc., are used for decision of initial mix proportions, and satisfactory mixture for required properties is then concluded after several trial mixes and adjustment. This kind of procedure is easy to follow, however intensive work is needed to obtain an optimal mixture proportion. And any change in source materials or application situation requires intensive re-testing and adjustments. For SCC, research has been conducted and several categories of design methods have been drawn, such as the compressive strength method, close aggregate packing method, statistical factorial model method, rheology of paste model method [1] These methods possess advantages including precisely determining quantity of specific ingredient, minimizing trial batches, simplifying test protocol, providing basis for quality control, etc., that can be considered as reference for SCAAMs design in the future.

Though several investigations have been conducted on the durability of SCAAMs, this kind of work is still limited in water absorption, acid and sulfate resistance, and data are interpretated in qualitative scale. The durability depends strongly on the nanoproperties and microstructure of reaction products and their interaction with surrounding 
environment. For reliable evaluation of durability and prediction of service life of SCAAMs, characterization under real-world service conditions with multiple modes of corrosion, figuring out key degradation mechanisms, understanding the interrelationships between microstructure and durability, are the key areas with need for future work.

\section{Conclusions}

Recent progress in SCAAMs are revisited and perspectives for further development are discussed in this work. Both fresh and hardened properties of SCAAMs are determined by physicochemical characteristics of source materials and mixture formulation. Though located in a similar range to conventional AAMs, the SCAAMs possess much better workability because of a proportional binder design, high paste-to-aggregate ratio, reduced coarse aggregate content. Benefiting from the accelerated dissolution of aluminosilicate components and formation of strength-giving products, increasing $\mathrm{Na}_{2} \mathrm{Oeq}$ content in binder can generally lead to an improvement in compressive strength. Adoption of fine additives like RHA and NS contributes to enhance mechanical properties and microstructure of obtained SCAAMs, reflecting as reduced water adsorption rate. Based on the general water adsorption values, SCAAMs can be classified as a good concrete category. The SCAAMs exhibited well acidic and sulfate resistance with low mass and strength loss. Optimization in mixture composition, such as increasing activator concentration, incorporating fine particles can further improve the acid and sulfate resistance of SCAAMs. SCAAMs also possess adequate impact energy, which can be considerable enhanced by incorporating steel fiber. The enhancement can be individually further improved by using long fiber or adding nanosilica, because of the high friction/adherence of long steel fiber with matrix and improvement in microstructure. In addition, excellent repair/rehabilitation property of SCAAMs was detected using both conventional and modified push-off tests. All these indicate that SCAAMs can be used as advanced construction materials for civil infrastructure.

Meanwhile, current production and characterization of SCAAMs are still in laboratory scale, and the decision for the initial mixture proportion was frequently based on empirical design method, requiring intensive work and adjustment to obtain optimal proportion. Advanced mix-design procedures should and need to be developed. Moreover, durability characterization of SCAAMs under real-world service condition with multiple modes of corrosion, figuring out key degradation mechanisms, understanding the interrelationships with microstructure, are required for reliable evaluation of durability and prediction of service life. Further work on these areas would contribute to the promotion of understanding and application of SCAAMs.

Author Contributions: Conceptualization, Z.S., X.F. and M.G.; Methodology, Z.S., X.F. and M.G.; Formal analysis, Z.S., Q.T., M.G. and X.H.; Writing-original draft, Z.S.; Writing-review \& editing, Q.T. and X.F.; Supervision, X.F., M.G.; Resources, X.C., Z.J.; Visualization, Z.J. All authors have read and agreed to the published version of the manuscript.

Funding: This research received no external funding.

Institutional Review Board Statement: Not applicable.

Informed Consent Statement: Not applicable.

Data Availability Statement: Not applicable.

Conflicts of Interest: The authors declare no conflict of interest.

\section{References}

1. Shi, C.; Wu, Z.; Lv, K.; Wu, L. A review on mixture design methods for self-compacting concrete. Constr. Build. Mater. 2015, 84, 387-398. [CrossRef]

2. Sonebi, M.; Yahia, A. Mix design procedure, tests, and standards. In Self-Compacting Concrete: Materials, Properties and Applications; Siddique, R., Ed.; Woodhead Publishing: Cambridgeshire, UK, 2020; pp. 1-30.

3. Okamura, H. Self-compacting high-performance concrete. Concr. Int. 1997, 19, 50-54. 
4. Ozawa, K.; Maekawa, K.; Kunishima, M.; Okamura, H. Development of high performance concrete based on the durability design of concrete structures. Proc. Second East Asia-Pac. Conf. Struct. Eng. Constr. 1989, 1, 445-450.

5. Rasekh, H.; Joshaghani, A.; Jahandari, S.; Aslani, F.; Ghodrat, M. Rheology and workability of SCC. In Self-Compacting Concrete: Materials, Properties and Applications; Siddique, R., Ed.; Woodhead Publishing: Cambridgeshire, UK, 2020; pp. 31-63.

6. Kashani, A.; Ngo, T. Production and placement of self-compacting concrete. In Self-Compacting Concrete: Materials, Properties and Applications; Siddique, R., Ed.; Woodhead Publishing: Cambridgeshire, UK, 2020; pp. 65-81.

7. Caijun, S.; Yanzhong, W. Mixture Proportioning and Properties of Self-Consolidating Lightweight Concrete Containing Glass Powder. ACI Mater. J. 2005, 102, 355-363.

8. Proceedings pro042: 1st International Symposium on Design, Performance and Use of Self-Consolidating Concrete (SCC'2005-China). Available online: https:// www.rilem.net (accessed on 28 October 2021).

9. Huseien, G.F.; Sam, A.R.M.; Shah, K.W.; Mirza, J. Effects of ceramic tile powder waste on properties of self-compacted alkaliactivated concrete. Constr. Build. Mater. 2020, 236, 117574. [CrossRef]

10. Goodier, C.I. Development of self-compacting concrete. Proc. Inst. Civ. Eng.-Struct. Build. 2003, 156, 4. [CrossRef]

11. EFNARC. Specification and Guidelines for Self-Compacting Concrete. 2002. Available online: https: / / efnarc.org/ (accessed on 28 October 2021).

12. Huseien, G.F.; Mirza, J.; Ismail, M.; Ghoshal, S.K.; Hussein, A.A. Geopolymer mortars as sustainable repair material: A comprehensive review. Renew. Sustain. Energy Rev. 2017, 80, 54-74. [CrossRef]

13. Garcia-Lodeiro, I.; Palomo, A.; Fernández-Jiménez, A.; MacPhee, D.E. Compatibility studies between N-A-S-H and C-A-S-H gels. Study in the ternary diagram $\mathrm{Na}_{2} \mathrm{O}-\mathrm{CaO}-\mathrm{Al}_{2} \mathrm{O}_{3}-\mathrm{SiO}_{2}-\mathrm{H}_{2} \mathrm{O}$. Cem. Concr. Res. 2011, 41, 923-931. [CrossRef]

14. Abdel-Gawwad, H.A.; Heikal, E.; El-Didamony, H.; Hashim, F.S.; Mohammed, A.H. Recycling of concrete waste to produce ready-mix alkali activated cement. Ceram. Int. 2018, 44, 7300-7304. [CrossRef]

15. Huseien, G.F.; Shah, K.W.; Sam, A.R.M. Sustainability of nanomaterials based self-healing concrete: An all-inclusive insight. J. Build. Eng. 2019, 23, 155-171. [CrossRef]

16. Huseien, G.F.; Mirza, J.; Ariffin, N.F.; Hussin, M.W. Synthesis and characterization of self-healing mortar with modified strength J. Teknol. 2015, 76, 195-200. [CrossRef]

17. Provis, J.L.; Bernal, S.A. Geopolymers and Related Alkali-Activated Materials. Annu. Rev. Mater. Res. 2014, 44, 299-327. [CrossRef]

18. Provis, J.L.; van Deventer, J.S.J. Alkali Activated Materials, 1st ed.; Springer: Dordrecht, The Netherlands, 2014.

19. Shi, C.; Roy, D.; Krivenko, P. Alkali-Activated Cements and Concretes; CRC Press: London, UK, 2003.

20. 70,000 Tonnes Geopolymer Concrete for Airport. Available online: https://www.geopolymer.org/news/70000-tonnesgeopolymer-concrete-airport (accessed on 28 October 2021).

21. Ahmed, M.F.; Nuruddin, M.F.; Shafiq, N. Compressive Strength and Workability Characteristics of Low-Calcium Fly ash-based Self-Compacting Geopolymer Concrete. Int. J. Civ. Environ. Eng. 2011, 2, 64-70.

22. Memon, F.A.; Nuruddin, M.; Demie, S.; Shafiq, N. Effect of curing conditions on strength of fly ash-based self-compacting geopolymer concrete. J. Civ. Environ. Eng. 2011, 5, 342-345.

23. Nuruddin, M.F.; Demie, S.; Ahmed, M.F.; Shafiq, N. Effect of superplasticizer and NaOH molarity on workability, compressive strength and microstructure properties of self-compacting geopolymer concrete. Int. J. Civ. Environ. Eng. 2011, 3, 812-820.

24. Henigal, A.M.; Sherif, M.A.; Hassan, H. Study on properties of self-compacting geopolymer concrete. IOSR-JMCE 2017, 14, 52-66. [CrossRef]

25. Memon, F.A.; Nuruddin, M.F.; Khan, S.; Shafiq, N.; Ayub, T. Effect of sodium hydroxide concentration on fresh properties and compressive strength of self-compacting geopolymer concrete. J. Eng. Sci. Technol. 2013, 8, 44-56.

26. Manjunath, R.; Narasimhan, M.C.; Umesh, K.M.; Shivam, K.; Bharathi, U.K.B. Studies on development of high performance, self-compacting alkali activated slag concrete mixes using industrial wastes. Constr. Build. Mater. 2019, 198, 133-147. [CrossRef]

27. Manjunath, R.; Narasimhan, M.C. An experimental investigation on self-compacting alkali activated slag concrete mixes. J. Build. Eng. 2018, 17, 1-12. [CrossRef]

28. Patel, Y.J.; Shah, N. Enhancement of the properties of ground granulated blast furnace slag based self-compacting geopolymer concrete by incorporating rice husk ash. Constr. Build. Mater. 2018, 171, 654-662. [CrossRef]

29. Vishnu, N.; Kolli, R.; Ravella, D.P. Studies on self-compacting geopolymer concrete containing flyash, GGBS, wollastonite and graphene oxide. Mater. Today Proc. 2021, 43, 2422-2427. [CrossRef]

30. Gülşan, M.E.; Alzeebaree, R.; Rasheed, A.A.; Nis, A.; Kurtoglu, A.E. Development of fly ash/slag based self-compacting geopolymer concrete using nano-silica and steel fiber. Constr. Build. Mater. 2019, 211, 271-283.

31. Sun, Z.; Vollpracht, A. Isothermal calorimetry and in-situ XRD study of the $\mathrm{NaOH}$ activated fly ash, metakaolin and slag. Cem. Concr. Res. 2018, 103, 110-122. [CrossRef]

32. Provis, J.L.; Palomo, A.; Shi, C. Advances in understanding alkali-activated materials. Cem. Concr. Res. 2015, 78, 110-125. [CrossRef]

33. Turmanova, S.; Genieva, S.; Vlaev, L. Obtaining some polymer composites filled with rice husks ash-A review. Int. J. Chem. 2012, 4, 62-89. [CrossRef]

34. Pode, R. Potential applications of rice husk ash waste from rice husk biomass power plant. Renew. Sustain. Energy Rev. 2016, 53, 1468-1485. [CrossRef] 
35. Raman, S.N.; Ngo, T.; Mendis, P.; Mahmud, H.B. High-strength rice husk ash concrete incorporating quarry dust as a partial substitute for sand. Constr. Build. Mater. 2011, 25, 3123-3130. [CrossRef]

36. Kishore, G.N.; Gayathri, B. Experimental study on rise husk ash and fly ash based geopolymer concrete using sand. IOP Conf. Ser. Mater. Sci. Eng. 2017, 225, 012273. [CrossRef]

37. Van, V.-T.-A.; Rößler, C.; Bui, D.-D.; Ludwig, H.-M. Rice husk ash as both pozzolanic admixture and internal curing agent in ultra-high performance concrete. Cem. Concr. Compos. 2014, 53, 270-278. [CrossRef]

38. Detphan, S.; Chindaprasirt, P. Preparation of fly ash and rice husk ash geopolymer. Int. J. Miner. Metall. Mater. 2009, 16, 720-726.

39. Fletcher, R.A.; MacKenzie, K.J.D.; Nicholson, C.L.; Shimada, S. The composition range of aluminosilicate geopolymers. J. Eur. Ceram. Soc. 2005, 25, 1471-1477. [CrossRef]

40. Van Tuan, N.; Ye, G.; van Breugel, K.; Copuroglu, O. Hydration and microstructure of ultra high performance concrete incorporating rice husk ash. Cem. Concr. Res. 2011, 41, 1104-1111. [CrossRef]

41. Sturn, P.; Gluth, G.J.G.; Brouwers, H.J.H.; Kuhne, H.C. Synthesizing one-part geopolymers from rice husk ash. Cem. Concr. Compos 2017, 37, 108-118.

42. Kim, Y.Y.; Lee, B.-J.; Saraswathy, V.; Kwon, S.-J. Strength and durability performance of alkali-activated rice husk ash geopolymer mortar. Sci. World J. 2014, 2014, 209584. [CrossRef] [PubMed]

43. Rattanasak, U.; Chindaprasirt, P.; Suwanvitaya, P. Development of high volume rice husk ash alumino silicate composites. Int. J. Miner. Metall. Mater. 2010, 17, 654-659. [CrossRef]

44. He, J.; Jie, Y.; Zhang, J.; Yu, Y.; Zhang, G. Synthesis and characterization of red mud and rice husk ash-based geopolymer composites. Cem. Concr. Compos. 2013, 37, 108-118. [CrossRef]

45. Kusbiantoro, A.; Nuruddin, M.F.; Shafiq, N.; Qazi, S.A. The effect of microwave incinerated rice husk ash on the compressive and bond strength of fly ash based geopolymer concrete. Constr. Build. Mater. 2012, 36, 695-703. [CrossRef]

46. Ardiantoro, D.; Sunarsih, E.S.; Sucipto, T.L.A. The role of rice husk ash in enhancing the fresh properties, density, and compressive strength of fly ash based self-compacting geopolymer concrete. J. Phys. Conf. Ser. 2021, 1808, 012014. [CrossRef]

47. Buyuknalcaci, F.N.; Polat, Y.; Negawo, T.A.; Döner, E.; Alam, M.S.; Hamouda, T.; Kilic, A. 24-Carbon nanotube-based nanocomposites for wind turbine applications. In Polymer-Based Nanocomposites for Energy and Environmental Applications; Jawaid, M., Khan, M.M., Eds.; Woodhead Publishing: Cambridgeshire, UK, 2018; pp. 635-661.

48. Shih, J.Y.; Chang, T.P.; Hsiao, T.C. Effect of nanosilica on characterization of Portland cement composite. Mater. Sci. Eng. A 2006, 424, 266-274. [CrossRef]

49. Zhang, M.H.; Li, H. Pore structure and chloride permeability of concrete containing nano-particles for pavement. Constr. Build. Mater. 2011, 25, 608-616. [CrossRef]

50. Said, A.M.; Zeidan, M.S.; Bassuoni, M.T.; Tian, Y. Properties of concrete incorporating nano-silica. Constr. Build. Mater. 2012, 36, 838-844. [CrossRef]

51. Pacheco-Torgal, F.; Miraldo, S.; Ding, Y.; Labrincha, J.A. Targeting HPC with the help of nanoparticles: An overview. Constr. Build. Mater. 2013, 38, 365-370. [CrossRef]

52. Shaikh, F.U.A.; Supit, S.W.M.; Sarker, P.K. A study on the effect of nano silica on compressive strength of high volume fly ash mortars and concretes. Mater. Des. 2014, 60, 433-442. [CrossRef]

53. Gao, K.; Lin, K.L.; Wang, D.; Hwang, C.L.; Anh Tuan, B.L.; Shiu, H.S.; Cheng, T.W. Effect of nano-SiO 2 on the alkali-activated characteristics of metakaolin-based geopolymers. Constr. Build. Mater. 2013, 48, 441-447. [CrossRef]

54. Adak, D.; Sarkar, M.; Mandal, S. Effect of nano-silica on strength and durability of fly ash based geopolymer mortar. Constr. Build. Mater. 2014, 70, 453-459. [CrossRef]

55. Wild, S.; Khatib, J.M.; O'Farrell, M. Sulphate resistance of mortar, containing ground brick clay calcined at different temperatures. Cem. Concr. Res. 1997, 27, 697-709. [CrossRef]

56. Turanli, L.; Bektas, F.; Monteiro, P.J.M. Use of ground clay brick as a pozzolanic material to reduce the alkali-silica reaction. Cem. Concr. Res. 2003, 33, 1539-1542. [CrossRef]

57. Toledo Filho, R.D.; Gonçalves, J.P.; Americano, B.B.; Fairbairn, E.M.R. Potential for use of crushed waste calcined-clay brick as a supplementary cementitious material in Brazil. Cem. Concr. Res. 2007, 37, 1357-1365. [CrossRef]

58. Gonçalves, J.P.; Tavares, L.M.; Toledo Filho, R.D.; Fairbairn, E.M.R. Performance evaluation of cement mortars modified with metakaolin or ground brick. Constr. Build. Mater. 2009, 23, 1971-1979. [CrossRef]

59. Sánchez De Rojas, M.I.; Marín, F.P.; Frías, M.; Rivera, J. Properties and performances of concrete tiles containing waste fired clay materials. J. Am. Ceram. Soc. 2007, 90, 3559-3565. [CrossRef]

60. Sun, Z.; Cui, H.; An, H.; Tao, D.; Xu, Y.; Zhai, J.; Li, Q. Synthesis and thermal behavior of geopolymer-type material from waste ceramic. Constr. Build. Mater. 2013, 49, 281-287. [CrossRef]

61. Tolinski, M. Overview of Fillers and Fibers. In Additives for Polyolefins; Tolinski, M., Ed.; William Andrew Publishing: Norwich, NY, USA, 2009; pp. 93-119.

62. Murphy, J. Modifying Specific Properties: Mechanical Properties-Fillers. In Additives for Plastics Handbook, 2nd ed.; Elsevier Science: Amsterdam, The Netherlands, 2001; pp. 19-35.

63. Ransinchung, R.N.G.D.; Kumar, B. Investigations on pastes and mortars of ordinary Portland cement admixed with wollastonite and microsilica. J. Mater. Civ. Eng. 2010, 22, 305-313. [CrossRef] 
64. Thomas, B.S.; Gupta, R.C.; Kalla, P.; Cseteneyi, L. Strength, abrasion and permeation characteristics of cement concrete containing discarded rubber fine aggregates. Constr. Build. Mater. 2014, 59, 204-212. [CrossRef]

65. Archez, J.; Texier-Mandoki, N.; Bourbon, X.; Caron, J.F.; Rossignol, S. Influence of the wollastonite and glass fibers on geopolymer composites workability and mechanical properties. Constr. Build. Mater. 2020, 257, 119511. [CrossRef]

66. Mañosa, J.; Cerezo-Piñas, M.; Maldonado-Alameda, A.; Formosa, J.; Giro-Paloma, J.; Rosell, J.R.; Chimenos, J.M. Water treatment sludge as precursor in non-dehydroxylated kaolin-based alkali-activated cements. Appl. Clay Sci. 2021, 204, 106032. [CrossRef]

67. Godoy, L.; Rohden, A.B.; Garcez, M.R.; Costa, E.B.; Dalt, S.; Andrade, J. Valorization of water treatment sludge waste by application as supplementary cementitious material. Constr. Build. Mater. 2019, 223, 939-950. [CrossRef]

68. Cremades, L.V.; Cusidó, J.A.; Arteaga, F. Recycling of sludge from drinking water treatment as ceramic material for the manufacture of tiles. J. Clean. Prod. 2018, 201, 1071-1080. [CrossRef]

69. Guo, X.; Shi, H.; Dick, W. Use of heat-treated water treatment residuals in fly ash-based geopolymers. J. Am. Ceram. Soc. 2010, 93, 272-278. [CrossRef]

70. Nimwinya, E.; Arjharn, W.; Horpibulsuk, S.; Phoo-ngernkham, T.; Poowancum, A. A sustainable calcined water treatment sludge and rice husk ash geopolymer. J. Clean. Prod. 2016, 119, 128-134. [CrossRef]

71. Waijarean, N.; Asavapisit, S.; Sombatsompop, K. Strength and microstructure of water treatment residue-based geopolymers containing heavy metals. Constr. Build. Mater. 2014, 50, 486-491. [CrossRef]

72. Geraldo, R.H.; Fernandes, L.F.R.; Camarini, G. Water treatment sludge and rice husk ash to sustainable geopolymer production J. Clean. Prod. 2017, 149, 146-155. [CrossRef]

73. Horpibulsuk, S.; Suksiripattanapong, C.; Samingthong, W.; Rachan, R.; Arulrajah, A. Durability against wetting-drying cycles of water treatment sludge-fly ash geopolymer and water treatment sludge-cement and silty clay-cement Systems. J. Mater. Civ. Eng. 2016, 28, 04015078. [CrossRef]

74. Suksiripattanapong, C.; Horpibulsuk, S.; Boongrasan, S.; Udomchai, A.; Chinkulkijniwat, A.; Arulrajah, A. Unit weight, strength and microstructure of a water treatment sludge-fly ash lightweight cellular geopolymer. Constr. Build. Mater. 2015, 94, 807-816. [CrossRef]

75. Hwang, C.; Chiang, C.; Huynh, T.; Vo, D.; Jhang, B.; Ngo, S. Properties of alkali-activated controlled low-strength material produced with waste water treatment sludge, fly ash, and slag. Constr. Build. Mater. 2017, 135, 459-471. [CrossRef]

76. Luukkonen, T.; Abdollahnejad, Z.; Yliniemi, J.; Kinnunen, P.; Illikainen, M. One-part alkali-activated materials: A review. Cem. Concr. Res. 2018, 103, 21-34. [CrossRef]

77. Nematollahi, B.; Sanjayan, J. Effect of Superplasticizers on workability of fly ash based geopolymer; Springer: Tanjong Pagar, Singapore, 2014; pp. 713-719.

78. Memon, F.A.; Nuruddin, M.F.; Demie, S.; Shafiq, N. Effect of superplasticizer and extra water on workability and compressive strength of self-compacting geopolymer concrete. Res. J. Appl. Sci. Eng. Technol. 2012, 4, 407-414.

79. Carabba, L.; Manzi, S.; Bignozzi, M.C. Superplasticizer addition to carbon fly ash geopolymers activated at room temperature. Materials 2016, 9, 9070586. [CrossRef]

80. Dener, M.; Karatas, M.; Mohabbi, M. High temperature resistance of self-compacting alkali activated slag/portland cement composite using lightweight aggregate. Constr. Build. Mater. 2021, 290, 123250. [CrossRef]

81. Nagaraj, V.K.; Venkatesh Babu, D.L. Formulation and performance evaluation of alkali-activated self-compacting concrete. Asian J. Civ. Eng. 2018, 19, 1021-1036. [CrossRef]

82. Huseien, G.F.; Sam, A.R.M.; Alyousef, R. Texture, morphology and strength performance of self-compacting alkali-activated concrete: Role of fly ash as GBFS replacement. Constr. Build. Mater. 2021, 270, 121368. [CrossRef]

83. Muttashar, H.L.; Ariffin, M.A.M.; Hussin, M.W.; Ishaq, S.B. Realisation of enhanced self-compacting geopolymer concrete using spent garnet as sand replacement. Mag. Concr. Res. 2018, 70, 558-569. [CrossRef]

84. Rahman, S.K.; Al-Ameri, R. A newly developed self-compacting geopolymer concrete under ambient condition. Constr. Build. Mater. 2021, 267, 121822. [CrossRef]

85. Australia Standard. Methods of Testing Concrete Determination of Properties Related to the Consistency of Concrete-Slump Flow T and J-Ring Test. Available online: https://infostore.saiglobal.com (accessed on 28 October 2021).

86. K, N.V.; Babu, D.L.V. Assessing the performance of molarity and alkaline activator ratio on engineering properties of selfcompacting alkaline activated concrete at ambient temperature. J. Build. Eng. 2018, 20, 137-155. [CrossRef]

87. Saini, G.; Vattipalli, U. Assessing properties of alkali activated GGBS based self-compacting geopolymer concrete using nano-silica. Case Stud. Constr. Mater. 2020, 12, 00352. [CrossRef]

88. Adesina, A. Performance and sustainability overview of alkali-activated self-compacting concrete. Waste Dispos. Sustain. Energy 2020, 2, 165-175. [CrossRef]

89. Huseien, G.F.; Shah, K.W. Durability and life cycle evaluation of self-compacting concrete containing fly ash as GBFS replacement with alkali activation. Constr. Build. Mater. 2020, 235, 117458. [CrossRef]

90. Škvára, F.; Kopecký, L.; Šmilauer, V.; Bittnar, Z. Material and structural characterization of alkali activated low-calcium brown coal fly ash. J. Hazard. Mater. 2009, 168, 711-720. [CrossRef] [PubMed]

91. Fernandez-Jimenez, A.; Puertas, F.; Arteaga, A. Determination of kinetic equations of alkaline activation of blast furnace slag by means of calorimetric data. J. Therm. Anal. Calorim. 1998, 52, 945-955. [CrossRef] 
92. Nuruddin, M.F.; Demie, S.; Shafiq, N. Effect of mix composition on workability and compressive strength of self-compacting geopolymer concrete. Can. J. Civ. Eng. 2011, 38, 1196-1203. [CrossRef]

93. Sun, Z.; Vollpracht, A. One year geopolymerisation of sodium silicate activated fly ash and metakaolin geopolymers. Cem. Concr. Compos. 2019, 95, 98-110. [CrossRef]

94. Xu, H.; Van Deventer, J.S.J. The geopolymerisation of alumino-silicate minerals. Int. J. Min. Process 2000, 59, 247-266. [CrossRef]

95. Davidovits, J. Chemistry of geopolymeric systems, terminology. In Proceedings of the 2nd International Conference on Geopolymer 99, Saint Qunentin, France, 1-2 July 1999; pp. 9-39.

96. Duxson, P.; Provis, J.L.; Lukey, G.C.; Mallicoat, S.W.; Kriven, W.M.; van Deventer, J.S.J. Understanding the relationship between geopolymer composition, microstructure and mechanical properties. Colloids Surf. A Physicochem. Eng. Asp. 2005, 269, 47-58. [CrossRef]

97. Fernández-Jiménez, A.; Palomo, A.; Sobrados, I.; Sanz, J. The role played by the reactive alumina content in the alkaline activation of fly ashes. Microporous Mesoporous Mater. 2006, 91, 111-119. [CrossRef]

98. Lee, N.K.; Jang, J.G.; Lee, H.K. Shrinkage characteristics of alkali-activated fly ash/slag paste and mortar at early ages. Cem. Concr. Compos. 2014, 53, 239-248. [CrossRef]

99. Wardhono, A.; Gunasekara, C.; Law, D.W.; Setunge, S. Comparison of long term performance between alkali activated slag and fly ash geopolymer concretes. Constr. Build. Mater. 2017, 143, 272-279. [CrossRef]

100. Fernández-Jiménez, A.; Palomo, A.; Criado, M. Microstructure development of alkali-activated fly ash cement: A descriptive model. Cem. Concr. Res. 2005, 35, 1204-1209. [CrossRef]

101. Niş, A.; Eren, N.A.; Çevik, A. Effects of nanosilica and steel fibers on the impact resistance of slag based self-compacting alkali-activated concrete. Ceram. Int. 2021, 47, 23905-23918. [CrossRef]

102. Mohamed, O. A review of durability and strength characteristics of alkali-activated slag concrete. Materials 2019, $12,1198$. [CrossRef]

103. Ganesan, N.; Abraham, R.; Deepa Raj, S. Durability characteristics of steel fibre reinforced geopolymer concrete. Constr. Build. Mater. 2015, 93, 471-476. [CrossRef]

104. Falah, M.; Obenaus-Emler, R.; Kinnunen, P.; Illikainen, M. Effects of activator properties and curing conditions on alkali-activation of low-alumina mine tailings. Waste Biomass Valorization 2020, 11, 5027-5039. [CrossRef]

105. Zhang, W.; Yao, X.; Yang, T.; Zhang, Z. The degradation mechanisms of alkali-activated fly ash/slag blend cements exposed to sulphuric acid. Constr. Build. Mater. 2018, 186, 1177-1187. [CrossRef]

106. Yıldırım, G.; Khiavi, F.E.; Anıl, Ö.; Şahin, O.; Şahmaran, M.; Erdem, R.T. Performance of engineered cementitious composites under drop-weight impact: Effect of different mixture parameters. Struct. Concr. 2020, 21, 1051-1070. [CrossRef]

107. Mohammadi, Y.; Carkon-Azad, R.; Singh, S.P.; Kaushik, S.K. Impact resistance of steel fibrous concrete containing fibres of mixed aspect ratio. Constr. Build. Mater. 2009, 23, 183-189. [CrossRef]

108. Ismail, S.; Ramli, M. Impact resistance of recycled aggregate concrete with single and hybrid fibers. MATEC Web Conf. $2016,47,02001$. [CrossRef]

109. Ganeshan, M.; Venkataraman, S. Interface shear strength evaluation of self-compacting geopolymer concrete using push-off test. J. King Saud Univ. Eng. Sci. 2020, 8, 1-10. [CrossRef] 